\title{
EFFECT OF THE DRY AND RAINY WEATHER ON THE IDARED AND GOLDEN REINDERS APPLE VARIETIES FRUIT QUALITY
}

\author{
Attila ILLÉS $S^{1}$ - Péter Tamás NAGY ${ }^{2}$ - Tamás LANG ${ }^{2}$ - \\ Zoltán SZABÓ ${ }^{3}$ - József NYÉKI ${ }^{3}$ - Miklós SOLTÉSZ ${ }^{3}$ \\ ${ }^{1,2,3}$ University of Debrecen Center of Agricultural and Applied Economic Scienses, Institute for Research and Development \\ H-4032 Debrecen, Böszörményi út 138. \\ portnoy01@gmail.com \\ ${ }^{3}$ College of Kecskemet, Faculty of Horticulture \\ H-6000 Kecskemét, Erdei Ferenc tér 1-3
}

Keywords: apple, fruit quality, temperature, precipitation

\begin{abstract}
Summary
Weather conditions have an important role in fruit production. In the last few decades, this role is increased and basically determines the fruit quality and quantity. Despite of this statement, there is but very few information about impacts caused by weather anomalies in Hungarian orchards. Regarding this, the relation between the external, and internal values of the Idared and Golden Reinders apple varieties, the changing of the temperature and precipitation in a dry year (2009) as well as in a rainy year (2010) were investigated. The examined apple varieties are grown at the same training system (rootstock, spacing, training, pruning system). The average weight, average diameter, acid content and soluble solids were higher in 2009 than in 2010, although the precipitation was higher in 2010. Due to the many rainy days the intensity of sunshine and the number of sunny days were less. To produce better quality it is very important the amount of the sunshine and heat, the optimal temperature and the precipitation rate.
\end{abstract}

\section{Introduction}

The determining factors of the fruit production competitiveness, including the weather factors had been counted among the constant factors. In recent years, due to the increased frequency of extreme weather these factors are becoming the more variable risk factor (Gonda, 2010) During the last 10 years, we experienced excesses of weather, a combination of unusual hot and dry summer with local storms coming with flood-like rain, but the temperature unequivocally shows its warming trend; the highest warming can be expected in the summer months. This trend will be lower in winter while the spring values will decrease the least. The expected growth of the maximum temperature values will be about $4.9-5.3{ }^{\circ} \mathrm{C}$ and minimum values will be probably $4.2-$ $4.8{ }^{\circ} \mathrm{C}$. The number of sweltering days and the too warm nights occurred 2-6 times more frequently. According to professional estimates, in summer, solar radiation will increase (supposedly the UV radiation, too). It is said that the increase of ordinary precipitation can also be expected, but there will not be any relation between the growth of temperature and precipitation. We have to reckon with the growth of the dry periods, in spite of the fact that the extreme growth of the heavy rain (flood, inland waters) will be periodic. The amount of the precipitation will not increase proportionally with the temperature and irradiation, especially even in the growing season. With these objects we have to count with more drought and meteoric drought (Terbe, 2009). The effect of the suddenly exploding warm spring in 2009 and the rainy spring weather in 2010 were manifested in blooming, too.

Earlier research has shown that the first impact of climate change on certain fruit species can already be observed. For example, since the end of the 1980's the blossoming of fruit trees in Germany has advanced by several days. The general growing season in Europe and Germany has been extended by 10 days during the last ten years (Chmielewski \& Rötzer 2001, 2002). Because of the earlier blossoming of trees, in some regions of Europe, the risk of late frost damages has increased (Sušnik \& Žust 2001, Zinoni et al. 2002, Anconelli et al. 2004). 


\section{Material and methods}

\section{Growing conditions}

Siófok belongs to the southern region of Balaton. The hours of sunshine are about 2000-2100 hour per year. In winter months we have about 260-280 hour while in summer months the average hours of sunshine are about 440-480 hours. In this region the sunny hours can be increased with the effect of the foehn. Numbers of winter days are between 25-35, and the frosty days work out about 80-100 days in the county. Numbers of frost-free days are about 200 days in the major part of the county, which is important from the point of view of agricultural production.

The temperature of the growing period is a very important physiological parameter. Its changing, decreasing or increasing, influences significantly the intensity of plant growth (Antal, 1998). If the optimal amount of water is available, the increasing of temperature raises the produced volume. (Nyéki, Soltész, Szabó, Lakatos, Racskó, 2005)

Generally, the differences of the average temperature are larger in the Transdanubian region. The increment of average temperature reaches $1.2-1.3{ }^{\circ} \mathrm{C}$ in this region. According to Figure 1 and 2 , the average temperature of the growing season (April-September) was $20{ }^{\circ} \mathrm{C}$ in 2009 , while in 2010 it was $17.7^{\circ} \mathrm{C}$ at Siófok (Fig.1 and 2).

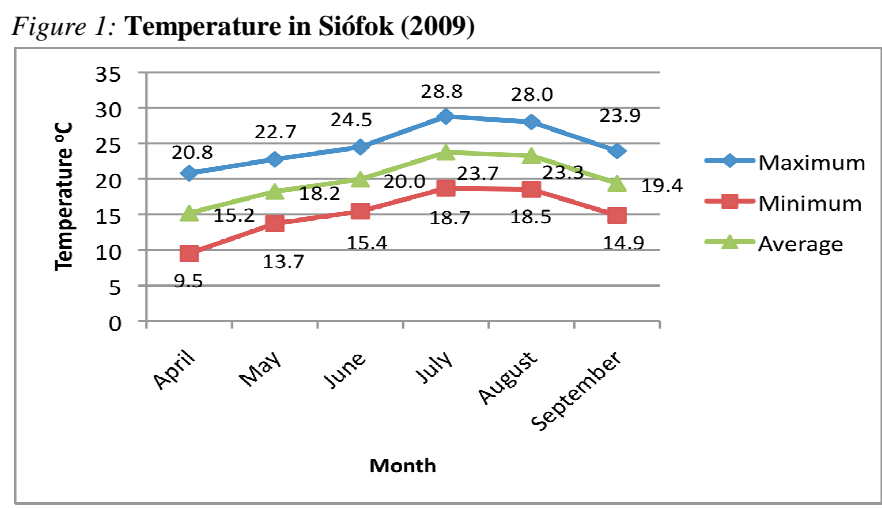

Source: Siofok Fruitgrowing Corporation

The sum of average temperatures in the last two years (2009 and 2010) was higher by $2.3{ }^{\circ} \mathrm{C}$ in the growing season, compared with the mean of many years.

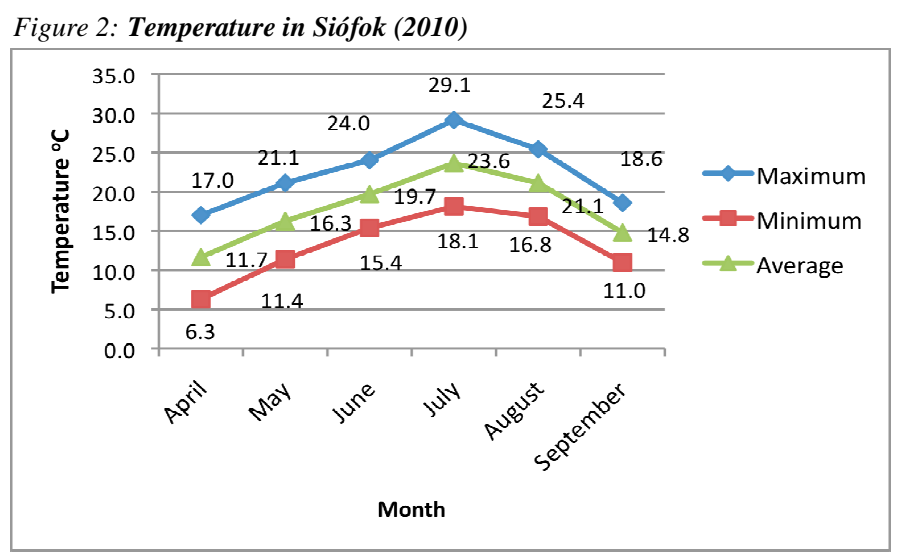

Source: Siofok Fruitgrowing Corporation

The average precipitation is $407-425 \mathrm{~mm}$ in the growing season. As opposed to the year of 2009 and 2010 there is a big difference (Fig. 3). The distribution of precipitation in 2009 was not extraordinary (Fig 3.) while in 2010 it was the opposite. The distribution of precipitation was similar but the amount is more than four times as much, which can modify the external, and internal parameters, including the average weight, average diameter, acid content and soluble solids. 


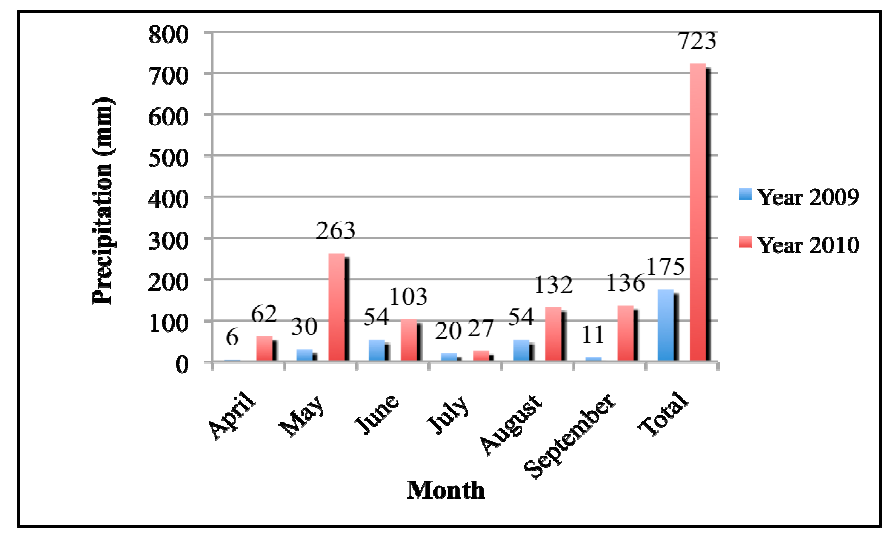

Source: Siofok Fruitgrowing Corporation

Following the distribution of precipitation and the hot summer, the apple orchard $(19,44$ ha) was irrigated with $53050 \mathrm{~m}^{3}$ water supplied from the Lake Balaton. This amount of water means $273 \mathrm{~mm}$ additional precipitation, in 2009. Table 1 shows the distribution of irrigated amount of water in 2009. Due to the rainy weather, the orchard was irrigated only in July using $7780 \mathrm{~m}^{3}$ water, which means $40 \mathrm{~mm}$ (additional) precipitation.

Table 1.Distribution of irrigations administered during the two years in $\mathrm{m}^{3}(2009,2010)$

\begin{tabular}{|c|c|c|}
\hline Month & Year 2009 & Year 2010 \\
\hline May & 18560 & - \\
\hline June & 7240 & - \\
\hline July & 8600 & 7780 \\
\hline August & 6600 & - \\
\hline September & 12050 & - \\
\hline Total & 53050 & 7780 \\
\hline
\end{tabular}

\section{Methods}

The examined matters and weather data are from the courtesy of the Siófok Fruit Growing Corporation. The weather database contains the following variables: monthly maximum temperature $\left({ }^{\circ} \mathrm{C}\right)$, monthly minimum temperature $\left({ }^{\circ} \mathrm{C}\right)$, monthly average temperature $\left({ }^{\circ} \mathrm{C}\right)$, and monthly precipitation $(\mathrm{mm})$. The examined apple varieties are grown at same the training system (rootstock, spacing, training, pruning system).

\section{Results}

The average diameter of Idared apple was bigger $(85.7 \mathrm{~mm})$ in 2009 than in $2010(80.3 \mathrm{~mm})$. The same is expressed by the mean fruit weights: $274.6 \mathrm{~mm}$ in 2009 and in 2010 the smaller fruits' weight are 204.2 (Table 2). The same has been observed in Golden Reinders (Table 2.), the difference between 2009 and $2010 \mathrm{is} 38.9 \mathrm{~g}$. The Idared apple's measured acid content was $3.4 \%$, which is by $0.9 \%$ higher than in 2010 . The Brix \% also shows higher values in 2009. The difference is $2.7 \%$. The measured acid content and soluble solids of 2009 (2.6\%) and 2010 (2.2\%) represent the same tendency in Golden Reinders as in Idared. The soluble solids also show higher values in 2009 (16.2\%) than in 2010 (15.7) (Table 3). By the copious precipitation in 2010, the average diameter, acid content and soluble solids should have been higher this year than in 2009, which was a very dry year according to Figure 3, too. 
Table 2: External parameters of Idared and Golden Reinders apples

\begin{tabular}{|c|c|c|c|c|}
\hline \multirow{2}{*}{ Year } & \multicolumn{4}{|c|}{ Variety } \\
\cline { 2 - 5 } & \multicolumn{2}{|c|}{ Idared } & \multicolumn{2}{c|}{ Golden Reinders } \\
\cline { 2 - 5 } & $\begin{array}{c}\text { Average } \\
\text { diameter } \\
(\mathrm{mm})\end{array}$ & $\begin{array}{c}\text { Average } \\
\text { weight }(\mathrm{g})\end{array}$ & $\begin{array}{c}\text { Average } \\
\text { diameter } \\
(\mathrm{mm})\end{array}$ & $\begin{array}{c}\text { Average } \\
\text { weight }(\mathrm{g})\end{array}$ \\
\hline 2009 & 85.7 & 274.6 & 85.7 & 212.5 \\
\hline 2010 & 80.3 & 204.2 & 75 & 173.6 \\
\hline
\end{tabular}

Table 3. Internal parameters of Idared and Golden Reinders apples

\begin{tabular}{|c|c|c|c|c|}
\hline \multirow{2}{*}{ Year } & \multicolumn{4}{|c|}{ Variety } \\
\cline { 2 - 5 } & \multicolumn{2}{|c|}{ Idared } & \multicolumn{2}{c|}{ Golden Reinders } \\
\cline { 2 - 5 } & $\begin{array}{c}\text { Acid } \\
\text { content } \% \text { \%) }\end{array}$ & $\begin{array}{c}\text { Soluble } \\
\text { solids } \\
(\text { Brix\%) }\end{array}$ & $\begin{array}{c}\text { Acid content } \\
(\%)\end{array}$ & $\begin{array}{c}\text { Soluble } \\
\text { solids (Brix } \\
\%)\end{array}$ \\
\hline 2009 & 3.4 & 14 & 2.6 & 16.2 \\
\hline 2010 & 2.5 & 11.3 & 2.2 & 15.7 \\
\hline
\end{tabular}

The vital process of fruit-bearing plants needs a particular regime of temperature. Differences from the optimum in both, positive and negative sense may impair productivity as well as quality of their fruit. An optimum of water supply is especially critical during the fruit growing period (from May to September) (Soltész, 1997).

Although the summer was extremely warm, sometimes intolerable hot in 2009 , we have to consider the fact that there was sufficient irrigation (Table 1.) according to the demand of the trees in order to approximate optimal weather conditions aiming to produce good quality fruits. High temperature should be counteracted by watering. In 2010, there was only one time for irrigation with $40 \mathrm{~mm}$ in July because of the $27 \mathrm{~mm}$ rain (Fig. 3). Water supply was many times more in 2010 than in 2009 , which should have cause better fruit quality because the availability of nutrients is getting better under wet soil conditions. But cloudy weather means less sunshine, which is an important factor to improve both inner and external parameters of fruits. To produce better fruit quality, the number of sunny hours and optimal temperature are very important. These effects were much fewer in 2010 than in 2009 . The average temperature was $17.7^{\circ} \mathrm{C}$, by $2.3{ }^{\circ} \mathrm{C}$ less than in 2009 . Lower temperature and less sunshine might have caused the lower values in average diameter, average weight, acid content and soluble solids. These results motivate us to continue our investigation to discover further statistic correlation.

\section{References}

Antal E. (1992): Az éghajlatváltozás hatása az aszályra Magyarországon. Beszámolók az 1988-ban végzett tudományos kutatásokról. Országos Meteorológiai Szolgálat, Budapest, 156-164.

Chmielewski F-M, Rötzer T. 2001: Response of tree phenology to climate change across Europe. Agricultural and Forest Meteorology, 108, 101-112.

Chmielewski F-M, Rötzer T 2002: Annual and spatial variability of the beginning of growing season in Europe in relation to air temperature changes. Clim. Res. 19(1), 257-264

Gonda I. (2010) MezőHír :: Mezőgazdasági Szaklap :: XIV. évfolyam

Nyéki J., Soltész M., Szabó Z., Lakatos L., Racskó J. (2005): Felkészülés a globális klímaváltozás kedvezőtlen hatásainak kivédésére a gyümölcstermesztésben

Soltész M. (1992): Virágzásfenológiai adatok és összefüggések hasznosítása az almaültetvények fajtatársításában. Doktori értekezés. MTA, Budapest.

Soltész M. (1997): Integrated Fruitgrowing, Mezőgazda kiadó, Budapest

Szabó Z. (2007):Gyümölcsültetvények termésszabályozása, termésbiztonság tényezői a gyümölcstermesztésben

Sušnik A. Žust A 2001: Phenological model for forecasting blossoming dates of plum tree as a tool for frost risk assessment related to

climate change. Conference abstract on Wageningen Phenology Conference. Holland. 5-7 December. 6 pp.

Terbe I. (2010) MezőHír :: Mezőgazdasági Szaklap :: XIV. évfolyam

Zinoni F. Antolini G. Campisi T. Marletto V. Rossi F 2002: Characterization of Emilia Romagna in relation with late frost risk. Chemistry and Physics of the Earth. 27. 1091-1101. 